\title{
UPAYA PENINGKATAN KEMANDIRIAN DAN KEWIRAUSAHAAN SISWA MELALUI PROGRAM SEKOLAH BERKEBUN
}

\author{
Rosmayati, Hasanuddin, dan Nini Rahmawati \\ Fakultas Pertanian Universitas Sumatera Utara \\ E-mail : rosmayati@usu.ac.id
}

\begin{abstract}
Abstrak
OSIS dan Unit Produksi SMKS IT Marinah Al-Hidayah Medan adalah dua elemen yang saling bekerja sama dalam pengembangan sekolah SMKS IT Marinah Al-Hidayah Medan. Unit Produksi yang merupakan wadah siswa untuk mengembangkan kreativitas, minat dan bakat sekaligus tempat siswa untuk menambah pengalaman serta penghasilan dengan berwirausaha. Kegiatan yang akan dilaksanakan adalah budidaya jamur tiram, pemanfaatan limbah baglog jamur dan limbah pertanian sebagai bahan baku kompos untuk digunakan sebagai media dalam pertanian sistem vertikultur. Namun, permasalah yang dihadapi adalah kesulitan pengadaan bibit jamur tiram berkualitas baik secara mandiri dan juga keterbatasan informasi mengenai kultur teknis budidaya jamur tiram, penanganan limbah baglog dan limbah pertanian dan pemanfaatan lahan sekolah untuk budidaya sayuran dengan metode vertikultur. Untuk membantu mengatasi permasalahan tersebut tim pengabdian pada masyarakat Fakultas Pertanian USU melalui Program Sekolah Berkebun melaksanakan pelatihan pembuatan bibit jamur tiram berkualitas baik dengan mengintroduksikan alat-alat pembuatan bibit jamur, alat press baglog dan pembuatan kumbung seluas $20 \mathrm{~m}^{2}$. Limbah baglog jamur dan limbah pertanian dari sekitar lingkungan sekolah selanjutnya diolah menjadi kompos dengan menggunakan mesin pencacah kompos. Kompos yang dihasilkan digunakan sebagai media tanam sayuran organik dengan menggunakan sistem budidaya vertikultur. Siswa juga dilatih untuk mengolah berbagai produk bahan makanan berbahan baku jamur tiram sehingga masa simpan, kandungan gizi dan nilai ekonomis jamur tiram dapat ditingkatkan sehingga dapat dipasarkan untuk melatih meningkatkan kemandirian dengan berwirausaha.
\end{abstract}

Kata kunci: Pendayagunaan, Kelompok diskusi, Mahasiswa, Radikalisme, Terorisme

\begin{abstract}
OSIS and Production Unit SMKS IT Marinah Al-Hidayah Medan are two elements that work together in the development of SMKS IT Marinah Al-Hidayah Medan. Production Unit which is media for students to develop creativity, interests and talents as well as place students to add experience and income with entrepreneurship. The activities to be carried out are the cultivation of oyster mushrooms, the utilization of mushrooms baglog waste and agricultural waste as compost raw material for use as a medium in vertical agricultural systems. However, the problem faced is the difficulty of supplying good quality oyster mushroom independently and also limited information about the technical culture of oyster mushroom cultivation, baglog waste handling and agricultural waste and utilization of school land for vegetable cultivation by vertikultur method. To help overcome these problems, the community service team of the Faculty of Agriculture USU through the Garden School Program conducts training on producing good quality oyster mushroom seeds by introducing mushroom seed making tools, press baglog and $20 \mathrm{~m}^{2}$ of growing room. Wastes baglog mushrooms and agricultural waste from around the school environment then processed into compost using compost machine. The resulting compost is used as a medium for planting organic vegetables using vertikulture cultivation system. Students are also trained to process a variety of food products made from oyster mushroom so that the shelf life, nutritional content and economic value of oyster mushrooms can be increased so it can be marketed to train to increase self-reliance with entrepreneurship.
\end{abstract}

Keywords: oyster mushroom, vertikultur, gardening school 


\section{PENDAHULUAN Latar Belakang}

Program Sekolah Berkebun merupakan program edukasi hijau yang bertujuan memberikan kesadaran sejak dini kepada para siswa akan pentingnya kelestarian dan keseimbangan lingkungan hidup. Edukasi hijau yang diberikan bersifat teoritis dan praktis sehingga pemahaman yang didapatkan bias diaplikasikan secara nyata dan memungkinkan terciptanya inovasi kreatif. Target dan tujuan Program Sekolah Berkebun adalah :

1. Siswa dan guru mendapatkan pemahaman dan ilmu pengetahuan tambahan mengenai lingkungan hidup dan budidaya hijau.

2. Siswa dan guru sadar pangan sehat dan bergizi

3. Proses pembelajaran produksi pangan sehat secara integrative

4. Media pembelajaran lapangan yang lengkap

5. Sekolah menjadi alternative basis-basis ketersediaan pangan sehat

6. Inovasi kreatif teknologi tepat guna baik untuk pertanian maupun lingkungan hidup.

Salah satu usaha pertanian yang sangat prospektif dan potensial untuk dikembangkan di sekolah melalui Program Sekolah Berkebun yaitu usaha budidaya jamur tiram (Pleurotus ostreatus) karena : 1. Daya serap pasar sangat tinggi dan semakin meningkat. 2. Kemungkinan stagnasi pasar sangat kecil karena merupakan konsumsi masyarakat sehari - hari 3. Bahan baku mudah diperoleh dan murah 4. Proses pemeliharaan tergolong mudah 5. Tidak memerlukan lahan yang luas 6. Kebutuhan skill tidak terlalu tinggi 7. Budidaya jamur tiram tidak mengenal musim sehingga dapat menghasilkan keuntungan terus menerus sepanjang tahun. 8. Jamur tiram merupakan pangan alternatif yang lezat, sehat dan bergizi tinggi, tidak menimbulkan pencemaran lingkungan. 9. Baglog bekas media tanam dapat digunakan untuk pupuk kolam ikan, campuran pakan ikan, campuran pakan ternak ,media memelihara cacing dan dapat dijadikan pupuk kompos .
Jamur tiram mengandung, air, serat zat besi, kalsium, vitamin B1, vitamin B2, dan vitamin $\mathrm{C}$, kandungan protein tinggi, kaya vitamin dan mineral, rendah karbohidrat, lemak dan kalori. Komposisi dan kandungan nutrisi setiap 100 gram jamur tiram adalah 367 kalori, 10,5-30,4 persen protein, 56,6 persen karbohidrat, 1,7-2,2 persen lemak, $0.20 \mathrm{mg}$ thiamin, 4.7-4.9 $\mathrm{mg}$ riboflavin, 77,2 $\mathrm{mg}$ niacin, dan $314.0 \mathrm{mg}$ kalsium. Kalori yang dikandung jamur ini adalah $100 \mathrm{kj} / 100$ gram dengan 72 persen lemak tak jenuh. Serat jamur sangat baik untuk pencernaan. Kandungan seratnya mencapai 7,4- 24,6 persen sehingga cocok untuk para pelaku diet. Jamur tiram ini memiliki manfaat kesehatan diantaranya, dapat mengurangi kolesterol dan jantung lemah serta beberapa penyakit lainnya. Jamur ini juga dipercaya mempunyai khasiat obat untuk berbagai penyakit seperti penyakit lever, diabetes, anemia (Susilawati dan Budi, 2010).

Unit Produksi dan OSIS SMKS IT Marinah Al-Hidayah Medan ingin mengembangkan kewirausahaan yaitu dengan membudidayakan jamur tiram. Pada Tim Pelaksana Pengabdian pada Masyarakat USU, Unit Produksi serta OSIS SMKS IT Marinah Al-Hidayah mengemukakan keinginan untuk mengembangkan budidaya jamur tiram terutama dari segi penyediaan bibit jamur berkualitas tinggi, pemanfaatan limbah baglog dan limbah pertanian sebagai media tanam verikultur, dan pengolahan jamur tiram menjadi berbagai produk olahan makanan.

Berdasarkan permasalahan mitra, tim pelaksana kegiatan pengabdian masyarakat berupa introduksi teknologi dan pengetahuan untuk meningkatkan produksi jamur tiram melalui teknik pembuatan bibit jamur tiram F0 sampai dengan $\mathrm{F} 1$, budidaya jamur tiram dengan memanfaatkan limbah baglog sebagai bahan baku kompos yang dapat digunakan untuk budidaya sayur organik, dan pengolahan jamur tiram menjadi berbagai produk makanan.

\section{METODE}

Metode pendekatan yang akan dilakukan untuk mendukung realisasi program pengabdian kepada masyarakat pada Unit Produksi dan 
Rosmayati. et al. Upaya Peningkatan Kemandirian Dan Kewirausahaan Siswa Melalui Program Sekolah Berkebun

OSIS SMKS IT Marinah Al-Hidayah Medan yaitu ceramah dan diskusi, pelatihan disertai praktek. Rencana kegiatan yang akan dilakukan adalah :

a. Ceramah dan diskusi tentang prospek dan cara budidaya jamur tiram.

b. Pelatihan pembuatan media biakan dan pembuatan bibit F0 dan F1

c. Pelatihan cara membuat rumah jamur yang baik, metode sterilisasi ruangan dan alat-alat.

d. Pelatihan pembuatan media jamur tiram dengan introduksi mesin press baglog

e. Pelatihan cara budidaya mulai dari penanaman bibit F1 sampai dengan cara memanen yang baik

f. Pelatihan pembuatan kompos berbahan baku limbah baglog dan limbah pertanian dengan introduksi mesin pencacah kompos g. Pelatihan budidaya sayuran dengan sistem vertikultur yang menggunakan media kompos.

h. Pelatihan pengolahan produk makananan berbahan baku jarum tiram.

Realisasi program pengabdian kepada masyarakat ini juga diharapkan mampu menumbuhkan jiwa kewirausahaan (enterpreneurship) di kalangan siswa dan memberikan inovasi (alih teknologi) dari kalangan Perguruan Tinggi (USU) kepada mitra melalui pelatihan pembuatan bibit dan budidaya jamur tiram, pembuatan kompos, budidaya sayuran dengan sistem vertikultur, pengolahan hasil panen jamur dan praktek langsung dalam setiap tahapan kegiatan.

Tabel 1. Rancangan Evaluasi Pengabdian Masyarakat Mono Tahun Non-PNBP USU

\begin{tabular}{|l|l|l|}
\hline \multicolumn{1}{|c|}{ Kriteria } & \multicolumn{1}{|c|}{ Indikator Pencapaian Tujuan } & \multicolumn{1}{c|}{ Tolok Ukur } \\
\hline $\begin{array}{l}\text { Pembuatan bibit F1 } \\
\text { jamur tiram }\end{array}$ & $\begin{array}{l}\text { Pemahaman anggota kelompok } \\
\text { mitra }\end{array}$ & $\begin{array}{l}\text { Anggota kelompok mitra } \\
\text { memahami cara pembuatan bibit } \\
\text { F1 jamur tiram }\end{array}$ \\
\hline $\begin{array}{l}\text { Pembuatan rumah } \\
\text { jamur (kumbung) yang } \\
\text { memenuhi persyaratan } \\
\text { budidaya jamur tiram }\end{array}$ & $\begin{array}{l}\text { Terlaksananya praktek langsung } \\
\text { pembuatan rumah jamur } \\
\text { (kumbung) seluas } 20 \mathrm{~m}^{2}\end{array}$ & $\begin{array}{l}\text { Anggota kelompok mitra telah } \\
\text { memahami cara pembuatan rumah } \\
\text { jamur (kumbung) yang memenuhi } \\
\text { persyaratan budidaya jamur tiram }\end{array}$ \\
\hline Budiaya jamur tiram & $\begin{array}{l}\text { Pemahaman anggota kelompok } \\
\text { mitra dan praktek budidaya jamur } \\
\text { tiram }\end{array}$ & $\begin{array}{l}\text { Anggota kelompok mitra } \\
\text { memahami budidaya jamur tiram } \\
\text { dan terdapat peningkatan produksi } \\
\text { jamur tiram sebesar 20\% }\end{array}$ \\
\hline $\begin{array}{l}\text { Teknik panen dan } \\
\text { pascapanen jamur } \\
\text { tiram }\end{array}$ & $\begin{array}{l}\text { Pemahaman anggota kelompok } \\
\text { mitra untuk kriteria panen dan } \\
\text { penangangan pasca panen jamur } \\
\text { tiram berkualitas }\end{array}$ & $\begin{array}{l}\text { Kualitas dan harga jual jamur yang } \\
\text { dihasilkan dapat meningkat dan } \\
\text { seuai dengan permintaan pasar }\end{array}$ \\
\hline $\begin{array}{l}\text { Pembuatan kompos } \\
\text { dari limbah baglog dan } \\
\text { limbah pertanian }\end{array}$ & $\begin{array}{l}\text { Pemahaman anggota kelompok } \\
\text { mitra untuk membuat kompos } \\
\text { dengan menggunakan mesin } \\
\text { pencacah yang diintroduksikan }\end{array}$ & $\begin{array}{l}\text { Anggota kelompok mitra mampu } \\
\text { membuat kompos berkualitas baik }\end{array}$ \\
\hline $\begin{array}{l}\text { Budidaya sayuran } \\
\text { dengan sistim } \\
\text { vertikultur }\end{array}$ & $\begin{array}{l}\text { Pemahaman anggota kelompok } \\
\text { mitra dan praktek budidaya } \\
\text { sayuran dengan sistem vertikultur }\end{array}$ & $\begin{array}{l}\text { Anggota kelompok mitra } \\
\text { memahami budidaya sayuran } \\
\text { sistem vertikulturdan terdapat } \\
\text { peningkatan produksi sayuran } \\
\text { sebesar 20\% }\end{array}$ \\
\hline
\end{tabular}


Rosmayati. et al. Upaya Peningkatan Kemandirian Dan Kewirausahaan Siswa Melalui Program Sekolah Berkebun

\begin{tabular}{|l|l|l|}
\hline $\begin{array}{l}\text { Pengolahan jamur } \\
\text { tiram menjadi berbagai } \\
\text { produk makanan }\end{array}$ & $\begin{array}{l}\text { Pemahaman mitra dan praktek } \\
\text { pembuatan produk olahan } \\
\text { berbahan baku jamur tiram }\end{array}$ & $\begin{array}{l}\text { Mitra memahami dan mampu } \\
\text { membuat produk pangan berbahan } \\
\text { baku jamur tiram }\end{array}$ \\
\hline
\end{tabular}

Kegiatan pengabdian kepada masyarakat ini perlu partisipasi aktif dari kedua belah pihak. Pihak Perguruan Tinggi (USU) harus berperan aktif dalam memberdayakan Unit Produksi dan OSIS SMKS IT Marinah Al-Hidayah Medan dengan melakukan proses alih teknologi dari kalangan Perguruan Tinggi ke petani. Demikian juga Unit Produksi dan OSIS SMKS IT Marinah Al-Hidayah Medan harus berperan aktif untuk terselenggaranya kegiatan dalam menyediakan tempat pelaksanaan praktek pembuatan rumah jamur (kumbung). Untuk kegiatan pembuatan baglog jamur, Unit Produksi dan OSIS SMKS IT Marinah Al-Hidayah Medan berpartisipasi dalam mengumpulan limbah pertanian dan menyediakan tempat pembuatan baglog. Unit Produksi dan OSIS SMKS IT Marinah AlHidayah Medan diharapkan memiliki sikap antusiasme tinggi untuk keberhasilan setiap tahapan budidaya jamur tiram dan memahami cara pembuatan bibit jamur tiram berkualitas tinggi, pembuatan baglog jamur, pembuatan kompos dan budidaya sayuran dengan sistem vertikultur. Kerja sama yang erat dan partisipasi aktif dari tim $\mathrm{I}_{\mathrm{b}} \mathrm{M}$ Perguruan Tinggi (USU) dan Unit Produksi serta OSIS SMKS IT Marinah AlHidayah Medan merupakan kunci yang menentukan keberhasilan program $\mathrm{I}_{\mathrm{b}} \mathrm{M}$.

Pasca kegiatan dilaksanakan maka tim pelaksana dan Unit Produksi dan OSIS SMKS IT Marinah Al-Hidayah Medan harus melakukan evaluasi kegiatan guna mengukur keberhasilan kegiatan yang telah dilakukan. Rancangan evaluasi kegiatan, langkah-langkah dan indikator yang digunakan dalam rancangan evaluasi tersaji pada Tabel 1.

\section{HASIL DAN PEMBAHASAN}

Dari pelatihan budiaya dan pembuatan bibit jamur tiram berkualitas baik dengan menggunakan media dari limbah pertanian terungkap bahwa mitra belum mengetahui cara budidaya dan pembuatan bibit sehingga mereka sangat antusias dalam mengikuti pelatihan dan aktif berdiskusi mengenai teknik budidaya dan pembuatan bibit jamur tiram.

Untuk pemilihan jamur tiram yang akan dijadikan tanaman induk (eksplan) karena tidak semua tubuh buah jamur tiram baik sebagai tanaman induk. Tanaman induk merupakan tubuh buah jamur tiram yang akan digunakan untuk pembuatan bibit F0. Jamur tiram yang baik mempunyai ciri-ciri seperti: 1). Jamur cukup dewasa, 2). Sehat dan bebas dari hama dan penyakit, 3). Jamur berumur sekitar 4 hari sebelum berkembang menjadi badan buah, 4). bebas dari kelainan fisik, bentuknya besar, berdaging tebal dan kokoh. Kegiatan yang juga diajarkan kepada mitra adalah cara sterilisasi media, alat-alat dan bekerja dalam kondisi yang aseptic. Selanjutnya dilakukan pelatihan pembuatan media F0 dan F1 untuk jamur tiram. Setelah diperoleh biakan murni jamur tiram yang disebut dengan bibit F0, kemudian mitra diajarkan cara memindahkan bibit F0 ke media F1 untuk dijadikan bibit F1 dan dari F1 menjadi bibit F2. Setelah lebih kurang 10 hari seluruh permukaan media F1 ditutupi dengan misellium jamur tiram. Untuk menghasilkan mutu jamur yang baik tentu sangat tergantung dari mutu bibitnya, bibit jamur tiram yang baik salah satunya ditandai dengan pertumbuhan miselium yang merata diseluruh media tumbuh. Setelah pelatihan dilaksanakan mitra mengerti cara memilih, membuat dan memperbanyak bibit jamur tiram. Diharapkan selanjutnya tidak ada lagi kendala dalam penyediaan dan kebutuhan bibit dan tidak lagi membeli bibit dari pulau pemasok bibit jamur. Sehingga dapat membantu memenuhi kebutuhan bibit jamur tiram berkualitas dan berpotensi meningkatkan penghasilan mitra sebagai produsen bibit jamur. 

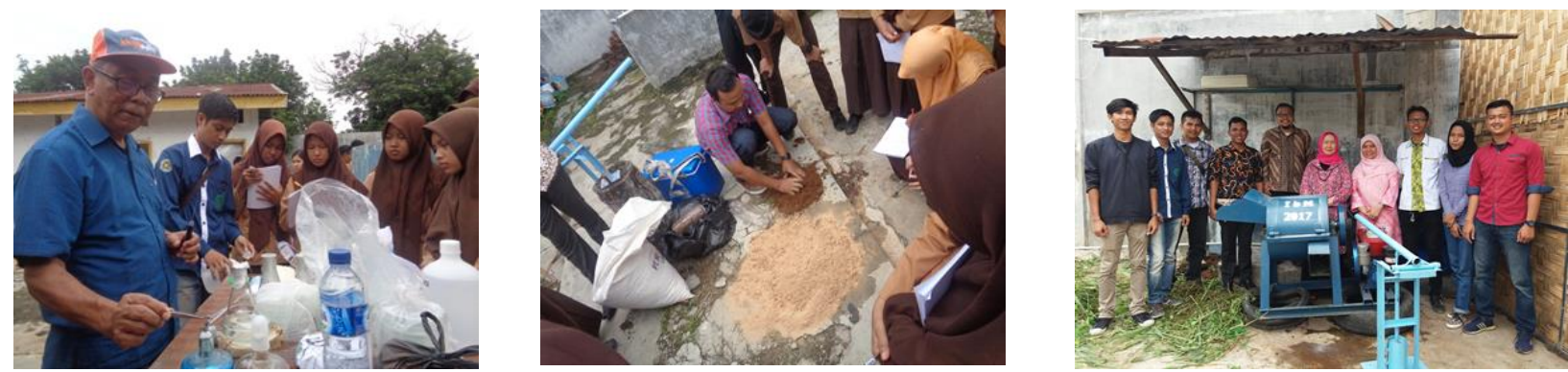

Gambar 1. Pembuatan bibit jamur, baglog dan serah terima mesin pencacah serta mesin press baglog

Pelatihan selanjutnya adalah cara memindahkan F1 atau F2 ke baglog. Riyanto (2010) menyebutkan bahwa terbatasnya produksi jamur tiram di Indonesia dikarenakan oleh beberapa faktor penghambat, salah satunya adalah penyedian bibit jamur yang berkualitas atau bibit yang bermutu. Bibit merupakan faktor yang sangat menentukan dalam proses budidaya jamur. Pembibitan merupakan tahapan budidaya yang memerlukan ketelitian tinggi karena harus dilakukan dengan keadaan steril dengan menggunakan bahan dan peralatan khusus. Sedangkan baglog yang merupakan media tanam dibuat dari limbah serbuk gergaji dengan menggunakan mesin press yang juga diberikan kepada mitra pada kegiatan ini.

Tahap berikutnya dari kegiatan pengabdian masyarakat ini adalah budidaya jamur tiram pada rumah jamur (kumbung) yang telah direnovasi sehingga memenuhi persyaratan sebagai tempat budidaya jamur tiram. Tahapan ini dimulai dari inokulasi. Inokulasi adalah proses pemindahan sejumlah kecil miselia jamur dari biakan induk kedalam media tanaman yang telah disediakan. Tujuannya adalah menumbuhkan miselia jamur pada media tanam hingga menghasilkan jamur yang siap panen. Tahap berikutnya adalah inkubasi yaitu menyimpan atau menempatkan media tanam yang telah diinokulasi pada kondisi ruang tertentu agar miselia jamur tumbuh. Inkubasi dilakukan hingga seluruh permukaan media tumbuh dalam baglog berwarna putih merata setelah 20-30 hari. Baglog yang telah putih ditumbuhi miselium dipindahkan ke kumbung budidaya. Hal yang terpenting harus diperhatikan dalam kumbung adalah menjaga suhu dan kelembaban yang dibutuhkan jamur.

Bila baglog yang digunakan permukaannya telah tertutup sempurna dengan miselium, biasanya dalam 1-2 minggu sejak pembukaan tutup baglog, jamur akan tumbuh dan sudah bisa dipanen. Baglog jamur bisa dipanen 5-8 kali, bila perawatannya baik. Baglog yang memiliki bobot sekitar $1 \mathrm{~kg}$ akan menghasilkan jamur sebanyak 0,7-0,8 kg. Setelah itu limbah baglog dapat dijadikan bahan kompos.

Pemanenan dilakukan terhadap jamur yang telah mekar dan membesar. Tepatnya bila ujung-ujungnya telah terlihat meruncing. Namun tudungnya belum pecah warnanya masih putih bersih. Bila masa panen lewat setengah hari saja maka warna menjadi agak kuning kecoklatan dan tudungnya pecah. Bila sudah seperti ini, jamur akan cepat layu dan tidak tahan lama. Jarak panen pertama ke panen berikutnya berkisar 2-3 minggu. 


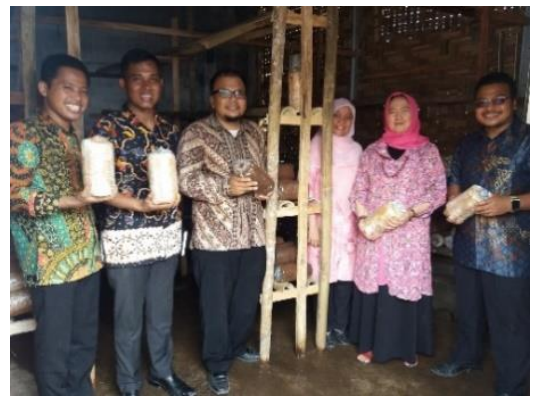

Gambar 2. Baglog jamur tiram pada Rumah jamur

Selanjutnya limbah baglog bersama dengan limbah pertanian yang berasal dari lingkungan sekitas sekolah dijadikan bahan baku pembuatan kompos. Untuk mempermudah dan mempercepat waktu pembuatan kompos ini, tim pelaksanan mengintroduksikan mesin pencacah kompos dan efektif mikroorganisme EM4. EM4 mampu merangsang pertumbuhan mikroorganisme tanah yang menguntungkan misalnya mikoriza, rhizobium, bakteri pelarut fosfat, dan lain-lain. Sehingga lebih banyak unsur hara yang mampu disediakan. Hasil dekomposisi sendiri selain menghasilkan unsurunsur tersedia bagi tanaman, juga menghasilkan senyawa organik yang dapat mengikat ion-ion yang berada dalam kondisi stabil (antioksidan)

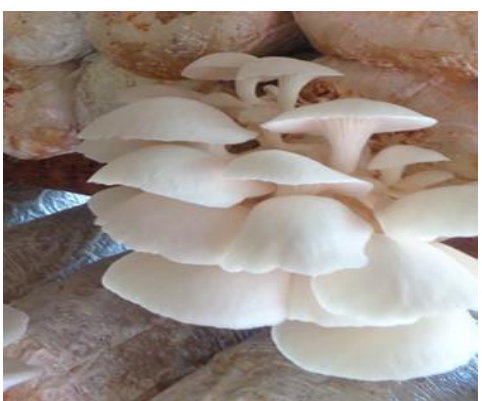

Gambar 3. Jamur tiram siap panen yang dibutuhkan tanaman (Higa dan Wididana, 1996). Mesin pencacah jerami padi yang diintroduksikan berguna memperkecil ukuran bahan baku pembuatan bokashi karena semakin kecil ukuran bahan kompos akan mempercepat proses pengomposan (dekomposisi). Hal ini karena adanya peningkatan luas permukaan bahan baku kompos untuk didekomposisi oleh mikroorganisme, memperluas daerah kontak dengan enzim bahan perombak. Pada tahapan ini terjadi proses hidrolisa membuka dindingdinding sel bahan organik (Sinar Tani, 2008). Disamping itu, ukuran bahan baku yang halus akan mengurangi pergerakan udara yang masuk ke dalam timbunan dan pergerakan $\mathrm{CO}_{2}$ yang keluar.

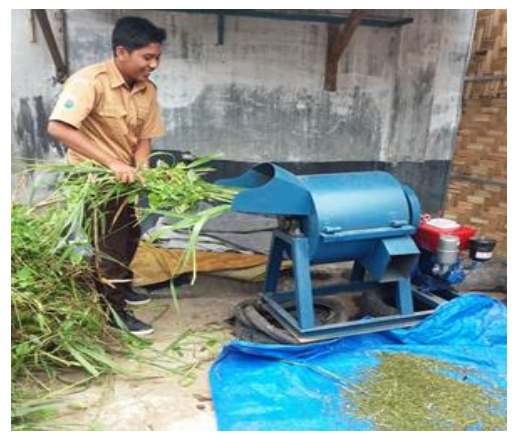

Gambar 4. Pembuatan kompos Dengan mesin
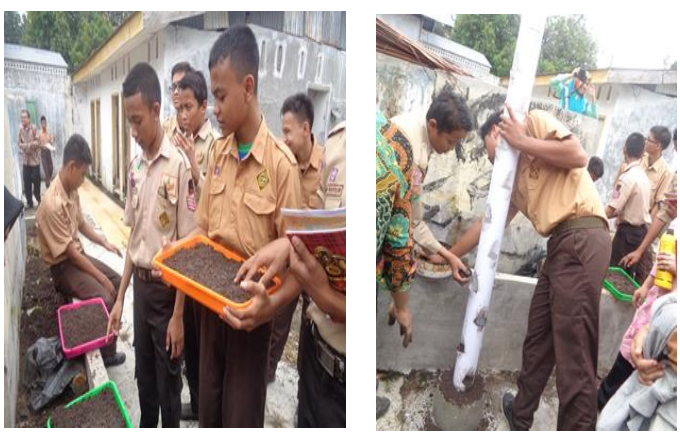

Gambar 5. Pembibitan dan penanaman sayur pada wadah vertikultur
Kompos yang dihasilkan digunakan sebagai media tanam sayuran organik yang dibudidayakan dengan sistem vertikultur. vertikultur adalah sistem budidaya pertanian yang dilakukan secara vertikal atau bertingkat, baik indoor maupun outdoor. Sistem budidaya pertanian secara vertikal atau bertingkat ini merupakan konsep penghijauan yang cocok 
untuk daerah perkotaan dan lahan terbatas (Lukman, 2015). Berbagai bahan dapat digunakan sebagai wadah media tumbuh tanaman, yang penting susunan wadah tetap memenuhi prinsip bahwa pertanaman dapat susun ke atas, namun tanaman bagian bawah masih memperoleh sinar yang cukup. Kolom vertikal dapat menggunakan pipa PVC (pralon), bamboo, pipa dari tanah (plempem). Kolom susun (mendatar) dapat berupa bambu, pralon, papan kayu, karung plastik/plastik/polybag/seng dengan kerangka bambu/kayu, pot gantung dari pot plastic, tempurung kelapa, kaleng bekas dan sebagainya. Pada kegiatan ini budidaya sayur organik dengan sistem vertikultur menggunakan wadah PVC yang diberi lubang kemudian diisi dengan media tanam berupa kompos kemudian bibit sayur ditanam pada wadah yang telah disiapkan. Pada kegiatan ini jenis sayuran yang dibudidayakan adalah sawi, kangkung dan selada.
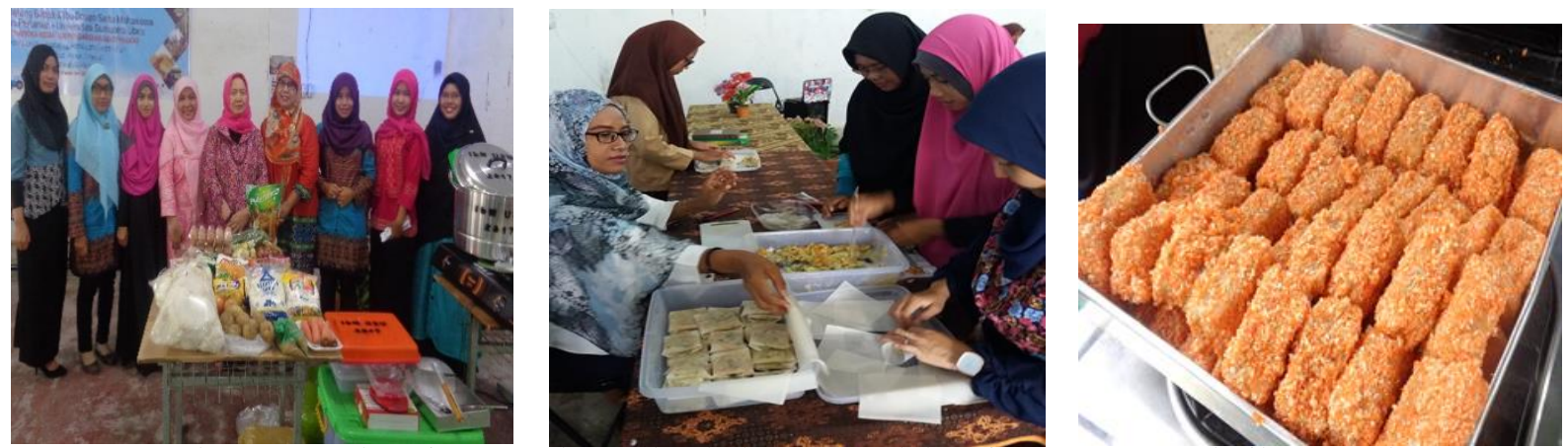

Gambar 6. Serah terima peralatan dan bahan pengolahan jamur, serta pelatihan pembuatan

Pembuatan produk makanan berbahan baku jamur tiram

Hasil panen jamur tiram memiliki masa simpan yang relatif singkat dan sangat mudah rusak sehingga nilai ekonomis cepat menurun. Pengolahan hasil komoditas menjadi berbagai macam produk menjadikan daya simpan lebih lama dan jangkauan pemasarannya lebih luas. Dengan dilakukan penerapan teknologi pengolahan yang tepat diharapkan petani dapat mengadopsi teknologi tersebut sehingga diperoleh produk olahan komoditas jamur tiram yang berkualitas, mendapatkan hasil yang lebih tinggi dan terbentuk home industri (Widowati et al, 2015). Pengolahan hasil pertanian khususnya komoditas jamur tiram menjadi salah satu alternatif untuk mengantisipasi hasil produksi berlimpah yang tidak dapat dipasarkan karena mutunya rendah. Hasil-hasil pertanian yang ukuran dan bentuknya tidak memenuhi standar mutu dapat dimanfaatkan menjadi berbagai macam hasil olahan sehingga dapat meningkatkan nilai tambah. Teknologi pengolahan yang digunakan sederhana dan dapat diterapkan ditempat petani sentra produksi. Dengan teknologi penanganan pasca panen yaitu pengolahan hasil dapat meningkatkan kelancaran pemasaran. Penyebab kurang stabilnya harga komoditas jamur tiram berkaitan dengan tidak dilakukannya pengolahan hasil oleh petani guna memperoleh nilai. Selain mendapatkan nilai tambah, kegiatan pengolahan hasil juga membuka peluang bagi pengembangan agroindustri di pedesaan (Syarief dan Halid, 1993).

Untuk mendukung pengolahan hasil panen jamur tiram menjadi berbagai produk olahan makanan, tim pelaksana menyerahkan peralatan pengolahan dan bahan-bahan yang dibutuhkan. Pada kegiatanan ini pelatihan pengolahan jamur tiram menjadi nuget jamur, bakso jamur dan martabak jamur. Kegiatan pengolahan ini diikuti dengan sangat antusias oleh guru-guru, siswa-siswa dan orang tua siswa. Dengan pengolahan berbagai produk pangan berbahan baku jamur tiram maka masa simpan, kandungan gizi dan nilai ekonomis jamur tiram semakin meningkat dan diharapkan dapat menumbuhkan jiwa kewirausahaan dan kemandirian siswa. 
Rosmayati. et al. Upaya Peningkatan Kemandirian Dan Kewirausahaan Siswa Melalui Program Sekolah Berkebun

\section{PENUTUP}

1. Kegiatan pengabdian masyarakat yang dilakukan telah berhasil dengan baik, OSIS dan Unit Produksi SMKS IT Marinah AlHidayah Medan sebagai khalayak sasaran sangat antusias dalam mengikuti setiap tahapan kegiatan pelatihan yang disertai praktek.

2. Pelatihan dan praktek langsung pembuatan bibit jamur tiram dan media tanam (baglog) dengan menggunakan alat press dan budidaya jamur tiram pada rumah jamur dikuti dengan antusias oleh mitra.

3. Limbah baglog jamur dan limbah pertanian dari lingkungan sekitar sekolah diolah menjadi kompos dengan menggunakan mesin pencacah kompos dan selanjutnya kompos dijadikan media tanam sayuran organik dengan sistem vertikultur.

4. Untuk meningkatkan masa simpan, kandungan gizi dan nilai ekonomis jamur tiram, mitra dilatih untuk mengolah hasil panen jamur tiram menjadi berbagai produk makanan olahan yaitu nuget jamur, bakso jamur dan martabak jamur.

5. Pelatihan dan praktek langsung budidaya jamur tiram, pembuatan kompos dari limbah baglog dan limbah pertanian, budidaya sayur organik dengan sistem vertikultur dan pengolahan hasil panen jamur tiram menjadi berbagai produk makanan olahan yang terintegrasi pada prorgam sekolah berkebun dapat meningkatkan kemandirian dan melatih siswa berwirausaha.

\section{UCAPAN TERIMA KASIH}

Penulis mengucapkan terima kasih yang sebesar-besarnya kepada Universitas Sumatera Utara, Lembaga Pengabdian Pada Masyarakat (LPPM) USU, OSIS dan Unit Produksi SMKS IT Marinah Al-Hidayah Medan yang telah memberi dukungan hingga terlaksananya kegiatan Pengabdian Masyarakat Mono Tahun Dana Non PNBP USU 2017 dengan Surat Perjanjian Penugasan Pelaksanaan Pengabdian kepada Masyarakat Nomor : 3221/UN5.2.3.2.1/PPM/2017, Tanggal 24 Juli 2017.

\section{DAFTAR PUSTAKA}

Hartini. 2012. Pemanfaatan Batang Jagung (Zea mays L.) Sebagai Campuran Media Tanam Pada Budidaya Jamur Merang (Volvariella volvacea). Undergraduate Tesis. Yogyakarta: UKDW.

Lukman, F. 2016. Teknologi Budidaya Tanaman Sayuran Secara Vertikultur. Balai Penelitian Tanaman Sayuran. Lembang. Bandung

Riyanto, F. 2010. Pembibitan Jamur Tiram (Pleurotus ostreatus) di Balai Pengembangan dan Promosi Tanaman Pangan dan Hortikultura (BPPTPH) Ngipiksari Sleman Yogyakarta. Fakultas Pertanian Universitas Sebelas Maret. Surakarta.

Sinar Tani. 2008. APPO Badan Litbang Pertanian Hasilkan Kompos Berkualitas dengan Biaya Minim. Sinar Tani On line.

Suharjo. E. 2007.Budidaya Jamur dengan Media Kardus.Agromedia Pustaka.Jakarta.

Sukmadi, H., N. Hidayat, dan E. R. Lestari. 2012. Optimasi Produksi Jamur Tiram Abu-abu (Pleurotus sajorcaju) Pada Campuran Serat Garut dan Jerami Padi. Produksi Jamur Tiram Abu-abu.. J. Tek. Pert.4(1) : 1 - 12

Sumiati, E., S. Sastrosiswojo, A.W.W. Hadisoeganda dan A. Hidayat. 2002. Identifikasi permasalahn budidaya jamur. Laporan Survey. Balai Penelitian Tanaman Sayuran. Lembang.

Sumiati, E., E. Suryaningsih, dan Puspitasari. 2006. Perbaikan Produksi Jamur Tiram dengan Modifikasi Bahan Baku Utama Media Bibit. J. Hort. 16 (2) :119-128. 
Rosmayati. et al. Upaya Peningkatan Kemandirian Dan Kewirausahaan Siswa Melalui Program Sekolah Berkebun

Sunarmi dan S. Cahyo. 2010. Usaha 6 Jenis Jamur Skala Rumah Tangga. Penebar Swadaya. Jakarta

Syarief, R dan H. Halid. 1993. Teknologi Penyimpanan Pangan. Arcan, Jakarta.
Widowati, R., M. Rizal, dan D. N. Purwantiningdyah. 2015. Teknologi pengolahan hasil jamur tiram serta analisis usaha taninya di Kota Balikpapan, Provinsi Kalimantan Timur. Prosiding Seminar Nasional Masyarakat Biodiversiti Indonesia. Volume 1, Nomor 2, April 2015. 